ISSN 2078-6441. Вісник Львівського університету. Серія географічна. 2013. Випуск 44. С. 161-169. Visnyk of the Lviv University. Series Geography. 2013. Issue 44. P. 161-169.

631.4

етян ктіонов , ксн ігун, ергій ейко, вітл н кісько
ціон льний н уковий центр
“нститут грунтозн вств m грохімї̈ імені . . околовського”,
вул. йковськ, 4, 61024, м. pків, кр їн,
e-mail: tnlaktionova@ukr.net

підст ві б г тофункціон льної повноцінної б зи д них “л стивості грунтів кр їни” розроблено лгоритм і з поч тков но створення реєстру просторово ідентифіков них ет лонних фізичних п р метрів основних орних грунтів кр їни для оцінюв ння їхньої фізичної якості. озр хунки інтегров ного індексу фізичної якості грунту виконують згідно із з п тентов ним втор ми способом, який грунтується н визн ченні грофізичного потенці лу грунту з сімом основними х р ктеристик ми. росторовою основою обр но природно-сільськогоспод рське p йонув ння, н йменшою просторовою одиницею - провінцію. прикл ді основних орних грунтів у івобережних провінціях зон ісостепу і тепу продемонстров но порядок розр хунків. відносними критеріями викон но порівняння фізичної якості грунтів різних типів у меж $\mathrm{x}$ кожної провінції.

лючові слов : індекс фізичної якості грунту, ет лон, природно-сільськогоспод рське р йонув ння, провінція.

уть оцінюв ння фізичної якості орного грунту ми вб ч ємо у порівнянні якості будь-якого грунту з якістю н йліпшого н лог т кого грунту в меж х просторової одиниці природно-сільськогоспод рського р йонув ння.

цінк фізичної якості перш з все з безпечує визн чення потенці лу грунту як об'єкт сільськогоспод рського використ ння і м є бути з стосов н у вирішенні пр ктичних пит нь щодо вибору культур, технологій вирощув ння, способів обробітку грунту, екологічної безпечності меліор цій, економічної ефективності інвестув ння, розр хунків в ртості земельних ділянок тощо.

йліпший грунт, бо ет лон-порівняння, є тр диційним в жливим елементом у 6 г тьох метод х оцінюв ння, н лізув ння й у пр ктичній діяльності з визн чення грономічного ст тусу грунту, бо грунтового покриву земельної ділянки. росторові одиниці природно-сільськогоспод рського р йонув ння ( ) кр їни є з конод вчо визн ною геогр фічною основою для викон ння будь-якого оцінюв ння грунтів, пов'яз ного з їхніми грономічними х р ктеристик ми. ідповідно до ст тті 179 емельного кодексу кр їни, розгляд ють як геогр фічну основу для оцінюв ння земель і розроблення землевпорядної документ ції щодо їхнього використ ння й охорони, згідно зі ст ттею 26 кону кр їни “ ро охорону земель”, - основою для поділу земель 3 цільовим призн ченням з ур хув нням природних умов, гробіологічних вимог сільськогоспод рських культур, спрямов ності сільськогоспод рської діяльності тощо.

(C) ктіонов ., ігун ., ейко . т ін., 2013 
ому визн чення ет лонних фізичних п р метрів грунтів певного генетичного типу і створення реєстру (б нку д них) ет лонних п р метрів, систем тизов них з просторовими одиницями природно-сільсько-господ рського р йонув ння, є пріоритетним 3 вд нням і в жливим ет пом роботи з оцінюв ння фізичної якості грунтів кр їни.

природно-сільськогоспод рським р йонув нням територія кр їни розділен н зони й гірські обл сті, д лі - н провінції, округи і природно-сільськогоспод рські p йони [7]. йонув ння викон но з ур хув нням грогрунтового, гроклім тичного, гідромеліор тивного т ерозійного р йонув нь н 6 зі фізико-геогр фічного. виділенні просторових одиниць (т ксонів) природно-сільськогоспод рського p йонув ння н йголовнішими ргумент ми були особливості грунтового покриву н рівні з іншими природними чинник ми грунтоутворення. они поділяють н природносільськогоспод рські провінції, які м ють ф ці льні особливості грунтового покриву, пов'яз ні з річними цикл ми режимів грунту. ровінції розрізняють з основними гроклім тичними х р ктеристик ми, що стосуються континент льності клім ту, тепло- т вологоз безпеченості рослин протягом вегет ційного періоду, періодичності т інтенсивності суховійних явищ, т кож з біологічною продуктивністю земель. ожній провінції, крім того, прит м нні свій н бір вирощув них сільськогоспод рських рослин, сортів т гротехнологій $[1,4,7]$.

меж х провінції можн виділити перелік грунтів, н яких тр диційно формуються основні площі ріллі. дн к ефективність землеробств й р ціон льність інвестув ння г лузі, звич йно ж з леж ть від грономічної якості грунтів, як визн чен їхніми вл стивостями.

ля н йпоширеніших орних грунтів у меж х кожної з дев'ятн дцяти природносільськогоспод рських провінцій кр їни необхідно м ти реєстр ет лонних (н йліпших) п р метрів фізичних вл стивостей, з якими можн було б порівнюв ти будь-який грунт у процесі його оцінюв ння і визн чення грономічної ( бо гровиробничої) якості.

ш мет - створити реєстр (б нк) ет лонних фізичних п р метрів основних орних грунтів кр їни для оцінюв ння їхньої якості.

сновним джерелом інформ ції для визн чення фізичної якості основних орних грунтів у меж х провінції природно-сільськогоспод рського р йонув ння і створення реєстру ет лонних фізичних п р метрів $є \quad 3$ д них “л стивості грунтів кр їни” $[2,3]$, як сьогодні містить відомості про розподіл вл стивостей у генетичних горизонт х 2010 профілів, з кл дених н всій території кр їни.

б’єкт дослідження - фізичні вл стивості грунтів кр їни.

ля розр хунків використ но з п тентов ний спосіб оцінюв ння фізичної якості грунту [5], згідно з яким, з основні індик тори якості взято т кі пок зники: 1) потужність гумусового, бо першого від поверхні генетичного горизонту, см;

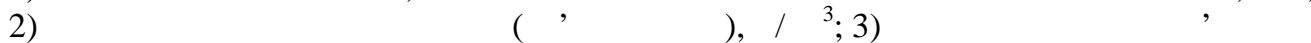
рослин, \%; 4) н йменш (польов ) вологоємність, \%; 5) уміст м кро грег тів грономічно корисного розміру - 0,25-10,0 мм, \%; 6) уміст водостійких грег тів розміром пон д 1 мм, \%; 7) сум рн питом поверхня елемент рних (гр нулометричних) ч сточок грунту від 1,0 до менше $0,001 \mathrm{мм}, \mathrm{m}^{2} / \Gamma$.

ибір індик торів якості т способу розр хунку індивіду льних індексів (відносних п р метрів кожного з індик торів) обгрунтов но після н лізу великого обсягу суч сних публік цій, де н йбільш цитов ними втор ми є I. рлен, . тот т . ор н [8, 9]. йпоширеніший спосіб співвідношення середнього п р метр у вибірці з гр ничним (більший від м ксим льного в 1,1 р 3 ), що ми і взяли з основу. 
нтегров ний індекс фізичної якості грунту зн ходимо з сумою семи індивіду льних індексів і потім, з мірою його відхилення від індексу ет лонного грунту н конкретній території, визн ч ємо ступінь оптим льності фізичної якості досліджув ного грунту (\%).

ей п р метр і використовуємо для кінцевих оцінок - чим меншим є відхилення фізичної якості грунту від ет лонної (для цього типу, підтипу й гр нулометричного скл ду у меж х провінції), тим ліпший $\epsilon$ цей грунт в грономічному розумінні.

ля створення вибірок 3 вр хов но т кі ргументи: геогр фічні - зон і провінція ; грунтово-кл сифік ційні - тип, підтип, вид, різновид (гр нулометричний скл д) і код грунту н к рті м сшт бу 1:2 500000 [6].

озр хунок площ грунтів викон но з допомогою електронної к рти грунтів м сшт бу 1:1 500000 у форм ті MapInfo.

дев’ятн дцяти провінцій природно-сільськогоспод рського р йонув ння кр їни ( $\quad$ ) вибр ли дві - івобережну провінцію ісостепу т івобережну провінцію тепу для відпр цюв ння методики роботи зі створення реєстру ет лонних п р метрів. ерелік основних орних грунтів н території цих двох провінцій з озн ченням ч стки в структурі грунтового покриву провінції, н ведено в т бл. 1.

блиця 1

ерелік основних орних грунтів н території двох провінцій кр їни

\begin{tabular}{|c|c|c|c|}
\hline $\begin{array}{c}\text { он } \\
\text { провінція }\end{array}$ & $\begin{array}{c}\text { омпонент грунтового покриву } \\
\text { (з } \\
\text { легендою до к рти грунтів м сшт бу } \\
1: 2500000 \text { [6]) }\end{array}$ & $\begin{array}{l}\text { р нуломет- } \\
\text { ричний } \\
\text { скл д* }\end{array}$ & $\begin{array}{l}\text { стк у структурі } \\
\text { грунтового покриву } \\
\text { провінції, \% }\end{array}$ \\
\hline \multirow{7}{*}{ 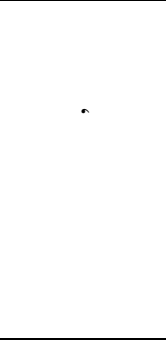 } & $6-$ сно-сірі т сірі лісові & 4,5 & 3,7 \\
\hline & 7 - емно-сірі опідзолені & $\begin{array}{l}4,5 \\
6,7\end{array}$ & $\begin{array}{l}5,6 \\
2,1\end{array}$ \\
\hline & \multirow{2}{*}{8 - орноземи опідзолені } & 4,5 & 3,6 \\
\hline & & 6,7 & 1,2 \\
\hline & $10-$ орноземи регр дов ні & 6,7 & 2,7 \\
\hline & \multirow[t]{2}{*}{$\begin{array}{l}11 \text { - орноземи типові м логумусні т } \\
\text { сл богумусов ні }\end{array}$} & $\begin{array}{l}4,5 \\
67\end{array}$ & 33,0 \\
\hline & & $\frac{6,7}{67}$ & $\frac{1,0}{139}$ \\
\hline \multirow{8}{*}{ 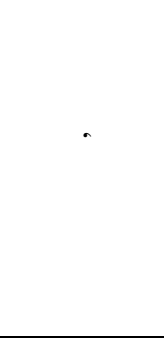 } & \multirow{3}{*}{$\begin{array}{l}13 \text { - орноземи звич йні м ло- і середньо- } \\
\text { гумусні глибокі }\end{array}$} & $\frac{0,1}{5}$ & $\frac{13,9}{0.6}$ \\
\hline & & 6 & 1,0 \\
\hline & & 7,8 & 8,7 \\
\hline & \multirow{2}{*}{14 - орноземи звич йні середньогумусні } & 5 & 0,1 \\
\hline & & 8 & 20,8 \\
\hline & 15 - орноземи звич йні м логумусні & $\begin{array}{c}6 \\
7,8\end{array}$ & $\begin{array}{l}10,3 \\
14,9\end{array}$ \\
\hline & \multirow{2}{*}{$\begin{array}{l}16 \text { - орноземи звич йні м логумусні } \\
\text { неглибокі }\end{array}$} & 6 & 1,6 \\
\hline & & 7,8 & 7,5 \\
\hline
\end{tabular}

рунти цих двох н йбільших провінцій у природних зон х ісостепу i тепу у 6 зі д них предст влені н йширше. г льн кількість опис них розрізів грунтів різних типів ст новить у івобережній провінції ісостепу -388 , тепу -891 .

к 6 чимо 3 т бл. 1, н йпоширенішими грунт ми в ісостеповій івобережній провінції є чорноземи типові м логумусні т сл бкогумусов ні (11) легко- т середньо 
суглинкові, у теповій - чорноземи звич йні середньогумусні (14) т м логумусні (15) в жкосуглинкові т глинисті.

прикл ді цих н йпоширеніших грунтів продемонструємо лгоритм оцінюв ння фізичної якості грунтів і порядок створення реєстру (б нку) ет лонних фізичних п р метрів.

к уже з зн чено, суть оцінюв ння ми вб ч ємо у порівнянні фізичної якості будьякого грунту н території природно-сільськогоспод рської просторової одиниці 3 якістю н йліпшого н лог т кого грунту (з ур хув нням гр нулометричного скл ду) н цій території.

ля розр хунку індексу фізичної якості грунту ( ), який н звемо “оцінюв ний грунт”, необхідно викон ти декільк т ких опер цій:

1) створити вибірки кожного з перелічених у т бл. 1 грунтів, включ ючи до них розрізи, що розміщені н території провінції, і д ти х р ктеристики вибірок. оловною $\mathrm{x}$ р ктеристикою, потрібною для под льших розр хунків, $\epsilon$ гр ничний п р метр кожного з семи індик торів, з якими розр ховують , згідно з методикою, н яку отрим но п тент [5];

2) розр хув ти індивіду льні індекси фізичної якості для кожного з семи індик торів, зн йти середнє зн чення індивіду льного індексу у вибірці; вибр ти н йліпший індивіду льний індекс у вибірці.

3) розр хув ти індекс фізичної якості н йліпшого грунту - ет лон порівняння;

4) розр хув ти індекс фізичної якості оцінюв ного грунту;

5) розр хув ти ступінь оптим льності фізичної якості оцінюв ного грунту, \% - міру відхилення від якості ет лонного (н йліпшого) грунту.

озглянемо н декількох прикл д х особливості викон ння розр хунків. т бл. 2 н ведено х р ктеристику вибірки з б зи д них “ л стивості грунтів кр їни” грунтових профілів чорнозему типового м логумусного легко- т середньосуглинкового. о вибірки взято 55 розрізів, які з кл дено н території івобережної провінції ісостепу. рунти, опис ні розріз ми, м ють усі відповідні х р ктеристики і вл стивості, що д ло змогу присвоїти їм код 11, під яким у легенді до к рти грунтів м сшт бу 1:1 500000 об'єдн но чорноземи типові сл бкогумусов ні і м логумусні.

и опр цюв ли вибірку з , до якої ввійшло 55 розрізів чорноземів типових м логумусних і сл бкогумусов них (11) легко- і середньосуглинкових, і отрим ли всі необхідні п р метри для оцінюв ння т кого грунту в меж х провінції - гр ничні і н йліпші п р метри семи фізичних вл стивостей грунтів, т кож розр хув ли індивіду льні індекси і зн йшли серед них н йліпші. ум н йліпших індексів д $\epsilon$ н м індекс фізичної якості н йліпшого грунту (ет лон), який ст новить 5,73.

епер оцінимо ре льний грунт. цінюв ний об'єКт розмішений у умській обл., ебединському р-ні. озріз № 2813 кл дено поблизу с. икове н вирівняному пл то. еогр фічні координ ти: довгот - 50,46,30, широт - 34,27,30, висот н д рівнем моря - 180 м. рунт - чорнозем типовий глибокий м логумусний високоз кип ючий середньосуглинковий н лесоподібному суглинку. ре льними п р метр ми фізичних вл стивостей оцінюв ного грунту у гумусовому генетичному горизонті т гр ничними п р метр ми у вибірці розр хув ли індивіду льні індекси і потім інтегров ний , який дорівнює 3,88. івст вленням оцінюв ного грунту у умській обл. $(3,88)$ з

н йліпшого грунту у вибірці $(5,73)$ виявили, що фізичн якість оцінюв ного грунту (ступінь оптим льності) ст новить $68 \%$ від н йліпшої, тобто м ксим льно можливої якості грунту цього типу і гр нулометричного скл ду н території івобережної 
провінції ісостепу. д них т бл. 2 б чимо, що індивіду льні індекси оцінюв ного н ми грунту м ло відрізняються від середніх у вибірці і його ступінь оптим льності лише н $2 \%$ вищий від середнього зн чення у вибірці. обто оцінюв ний грунт 3 грофізичним ст тусом є типовим для провінції і його цілком можн використовув ти для вирощув ння р йонов них культур т з стосув ння зон льних гротехнологій.

блиця 2

озр хунок чорноземів типових м ло гумусних і сл бкогумусов них (11) легко- і середньосуглинкових

\begin{tabular}{|c|c|c|c|c|c|c|c|c|c|}
\hline \multirow[b]{2}{*}{ Ок зник } & \multicolumn{7}{|c|}{ р метри окремих критеріїв у гумусовому горизонті } & & \multirow[b]{2}{*}{ 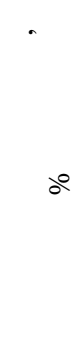 } \\
\hline & 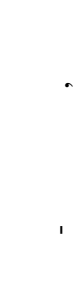 & 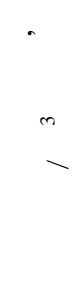 & 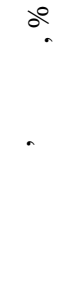 & 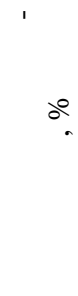 & 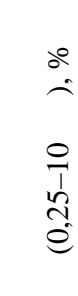 & 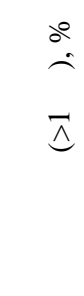 & 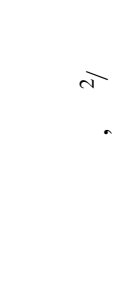 & & \\
\hline озмір вибірки $(n)$ & 55 & 49 & 42 & 40 & 14 & 14 & 45 & - & - \\
\hline $\begin{array}{c}\text { ксим льний } \\
\text { п р метр }(t)\end{array}$ & 54,0 & 1,52 & 12,9 & 34,8 & 83 & 50,5 & 15186,4 & - & - \\
\hline $\begin{array}{l}\text { р ничний п р метр } \\
(1,1 t)\end{array}$ & 59,4 & 1,67 & 14,2 & 38,3 & 91,3 & 55,5 & 16705,1 & - & - \\
\hline $\begin{array}{l}\text { ередній індивіду ль- } \\
\text { ний індекс у вибірці }\end{array}$ & 0,69 & 0,29 & 0,37 & 0,7 & 0,75 & 0,3 & 0,70 & 3,8 & 66 \\
\hline $\begin{array}{r}\text { йліпший індивіду - } \\
\text { льний індекс у вибірці }\end{array}$ & 0,91 & 0,48 & 0,7 & 0,91 & 0,91 & 0,91 & 0,91 & 5,73 & 100 \\
\hline $\begin{array}{l}\text { е льний п р метр } \\
\text { оцінюв ного грунту. } \\
\text { озріз № } 281\end{array}$ & 42,0 & 1,18 & 10,5 & 25,3 & 61,7 & 24,9 & 13841,0 & - & - \\
\hline $\begin{array}{l}\text { ндивіду льний індекс } \\
\text { оцінюв ного грунту. } \\
\text { озріз № } 281\end{array}$ & 0,71 & 0,29 & 0,26 & 0,66 & 0,68 & 0,45 & 0,83 & 3,88 & 68 \\
\hline
\end{tabular}

ет лоном ми можемо порівнюв ти як окремий грунт у меж х провінції, т к $\mathrm{i}$ середні (ліпше середньозв жені) п р метри вл стивостей грунту в меж $\mathrm{x} \quad \mathrm{p}$ йону бо в меж х дміністр тивної обл сті н території цієї провінції для того, щоб зн йти міру відхилення від оптимуму бо ступінь оптим льності фізичної якості досліджув ного грунту, \%. обто суть оцінюв ння будь-якого грунту зводиться до порівняння його з ет лонним, н йліпшим грунтом, який міг би існув ти н території з певними $\mathrm{x}$ р ктеристик ми чинників грунтоутворення.

икон ємо подібні опер ції зі степовим грунтом (див. т бл. 3).

цій вибірці т кож опр цьов но різну кількість розрізів 3 різними критеріями н йбільше д них стосується морфологічних озн к профілю і гідрофізичних х р ктеристик. озріз № 50 з кл дено поблизу с. ллічівське в ершотр вневому р-ні онецької обл. еогр фічні координ ти: довгот - 37,30,00, широт $-47,05,25$, висот н д рівнем моря - 60 м. рунт - чорнозем звич йний глибокий високоз кип ючий легкоглинистий н середньоглинистому лесі. 
ком ст новить 5,56, оцінюв ного грунту - 3,42, отже, ступінь його оптим льності оцінюють у $61 \%$, тобто він зн чно поступ ється можливому ет лону. ізичн якість оцінюв ного грунту є нижчою н віть від середнього індексу в меж х провінції (ступінь оптим льності середнього індексу по провінції - $64 \%$ ), тому, цілком імовірно, що грономічн пр ктик тут потребув тиме дешо більших зусиль і витр т, ніж н грунт х із ліпшими п р метр ми.

блиця 3

озр хунок чорноземів звич йних м ло- і середньогумусних глибоких (13) в жкосуглинкових і легкоглинистих

\begin{tabular}{|c|c|c|c|c|c|c|c|c|c|}
\hline \multirow[b]{2}{*}{ ок зник } & \multicolumn{7}{|c|}{ р метри окремих критеріїв у гумусовому горизонті } & & \multirow[b]{2}{*}{ 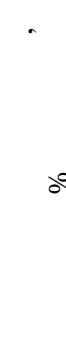 } \\
\hline & 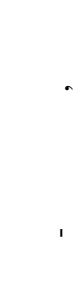 & 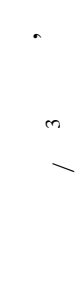 & 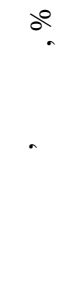 & 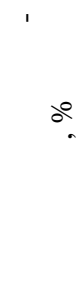 & 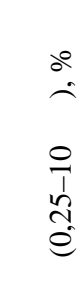 & 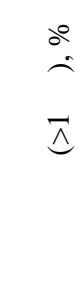 & 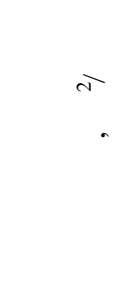 & & \\
\hline озмір вибірки $(n)$ & 56 & 54 & 50 & 51 & 34 & 34 & 41 & - & - \\
\hline $\begin{array}{l}\text { ксим льний } \\
\text { п р метр }(t)\end{array}$ & 58 & 1,43 & 17,8 & 40,4 & 93,3 & 51,3 & 22033 & - & - \\
\hline $\begin{array}{l}\text { p ничний п р метр } \\
(1,1 t)\end{array}$ & 63,8 & 1,57 & 19,6 & 44,4 & 102,6 & 56,7 & 24237 & - & - \\
\hline $\begin{array}{l}\text { ередній індивіду ль- } \\
\text { ний індекс у вибірці }\end{array}$ & 0,65 & 0,27 & 0,35 & 0,67 & 0,7 & 0,17 & 0,77 & 3,58 & 64 \\
\hline $\begin{array}{r}\text { йліпший індивіду - } \\
\text { льний індекс у вибірці }\end{array}$ & 0,91 & 0,43 & 0,58 & 0,91 & 0,91 & 0,91 & 0,91 & 5,56 & 100 \\
\hline \begin{tabular}{|l} 
е льний п р метр \\
оцінюв ного грунту. \\
озріз № 50 \\
\end{tabular} & 35 & 1,07 & 13,9 & 29,6 & 60,9 & 6,9 & 21555 & - & - \\
\hline $\begin{array}{c}\text { ндивіду льний індекс } \\
\text { оцінюв ного г грунту. } \\
\text { озріз № } 50\end{array}$ & 0,55 & 0,32 & 0,29 & 0,66 & 0,59 & 0,12 & 0,89 & 3,42 & 61 \\
\hline
\end{tabular}

ндекс фізичної якості грунту можн $з$ стосув ти і для непрямої оцінки спрямов ності еволюції основних предст вників грунтового покриву провінцій. творимо перелік середніх і ет лонних індексів фізичної якості грунтів, зіст вивши які, зн йдемо міру відхилення середнього зн чення від ет лон (див. т бл. 4), тобто середній ступінь оптим льності вл стивостей грунтів різних типів у провінції.

н лізу д них, н ведених у т бл. 4, можемо зробити висновок, що н йстійкішими до дегр д ційних, можливо, й еволюційних перетворень у меж х ісостепової івобережної провінції є чорнозем опідзолений в жкосуглинковий і легкоглинистий, в меж х тепової - чорнозем звич йний м логумусний неглибокий в жкосуглинковий. ередній цих грунтів н йменше відрізняється від ет лонного, що може свідчити про їхню відносну стійкість. йбільш вр зливим до еволюційних змін у ісостепу треб визн ти чорнозем типовий м логумусний легко- т середньосуглинковий, у групі степових чорноземів різниця менше помітн . 
тупінь оптим льності фізичної якості основних орних грунтів

\begin{tabular}{|c|c|c|c|c|c|}
\hline $\begin{array}{l}\text { он } \\
\text { провін- } \\
\text { ція }\end{array}$ & $\begin{array}{c}\text { омпонент грунтового покриву } \\
\text { (з легендою до к рти грунтів } \\
\text { м сшт бу } 1: 1500000)\end{array}$ & $\begin{array}{c}\text { р нуло- } \\
\text { метричний } \\
\text { скл д, код } \\
\text { у } \quad *\end{array}$ & $\begin{array}{r}\text { ередній } \\
\text { у } \\
\text { вибірці }\end{array}$ & $\begin{array}{l}\text { йліп- } \\
\text { ший } \\
\text { у } \\
\text { вибірці }\end{array}$ & $\begin{array}{l}\text { тупінь } \\
\text { оптим - } \\
\text { льності, } \\
\quad \%\end{array}$ \\
\hline \multirow{6}{*}{ 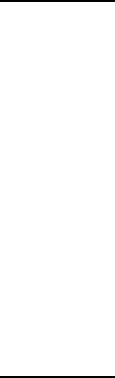 } & 6 - сно-сірі т сірі лісові & 4,5 & 2,75 & 3,49 & 79 \\
\hline & 7 - емно-сірі опідзолені & $\begin{array}{l}4,5 \\
6,7\end{array}$ & $\begin{array}{l}3,88 \\
4,26\end{array}$ & $\begin{array}{l}5,29 \\
5,62\end{array}$ & $\begin{array}{l}71 \\
76\end{array}$ \\
\hline & 8 - орноземи опідзолені & $\begin{array}{l}4,5 \\
6,7\end{array}$ & $\begin{array}{l}3,75 \\
3,28\end{array}$ & $\begin{array}{l}5,57 \\
3,93\end{array}$ & $\begin{array}{l}72 \\
83\end{array}$ \\
\hline & $10-$ орноземи регр дов ні & 6,7 & 2,48 & 3,38 & 73 \\
\hline & $\begin{array}{l}11 \text { - орноземи типові м ло- } \\
\text { гумусні т сл бкогумусов ні }\end{array}$ & $\begin{array}{l}4,5 \\
6,7\end{array}$ & $\begin{array}{l}3,80 \\
3,80\end{array}$ & $\begin{array}{l}5,73 \\
5,52 \\
\end{array}$ & $\begin{array}{l}66 \\
69 \\
\end{array}$ \\
\hline & $\begin{array}{l}12 \text { - орноземи типові середньо- } \\
\text { гумусні }\end{array}$ & 6,7 & 3,76 & 5,33 & 71 \\
\hline \multirow{4}{*}{ 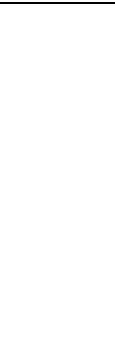 } & $\begin{array}{c}13 \text { - орноземи звич йні м ло- і } \\
\text { середньогумусні глибокі }\end{array}$ & $\begin{array}{c}5 \\
6,7 \\
8\end{array}$ & $\begin{array}{l}4,42 \\
3,58 \\
4,06\end{array}$ & $\begin{array}{l}5,41 \\
5,56 \\
5,37\end{array}$ & $\begin{array}{l}82 \\
64 \\
76\end{array}$ \\
\hline & $\begin{array}{c}14 \text { - орноземи звич йні } \\
\text { середньогумусні }\end{array}$ & $\begin{array}{l}5 \\
8\end{array}$ & $\begin{array}{l}4,33 \\
3,87\end{array}$ & $\begin{array}{l}5,79 \\
5,32\end{array}$ & $\begin{array}{l}75 \\
73\end{array}$ \\
\hline & $\begin{array}{c}15 \text { - орноземи звич йні } \\
\text { м логумусні }\end{array}$ & $\begin{array}{c}6,7 \\
8\end{array}$ & $\begin{array}{l}3,81 \\
4,25\end{array}$ & $\begin{array}{l}4,86 \\
5,15\end{array}$ & $\begin{array}{l}78 \\
82 \\
\end{array}$ \\
\hline & $\begin{array}{r}16 \text { - } \text { орноземи звич йні } \\
\text { м логумусні неглибокі }\end{array}$ & $\begin{array}{c}6,7 \\
8\end{array}$ & $\begin{array}{l}4,28 \\
3,77\end{array}$ & $\begin{array}{l}5,16 \\
5,22\end{array}$ & $\begin{array}{l}83 \\
72\end{array}$ \\
\hline
\end{tabular}

тже, використ ння повноцінної б зи д них вл стивостей грунтів кр їни д ло змогу з поч ткув ти створення реєстру просторово ідентифіков них ет лонних фізичних п р метрів основних орних грунтів кр їни як норм тивної основи для оцінюв ння фізичної якості грунту в меж х провінції природно-сільськогоспод рського $\mathrm{p}$ йонув ння.

\section{СПИСОК ВИКОРИСТАНОЇ ЛІТЕРАТУРИ}

1. $\quad$ н $ш$. риродно-сільськогоспод рське р йонув ння кр їни: виокремлення природно-сільськогоспод рських провінцій / . . н ш, . . сипчук, . . ртин, . . ерношт н // емлеустрій і к д стр. - 2006. - № 3. - . 6-25.

2. ктионов . . 3 д нных “ войств почв кр ины” (структур и порядок использов ния). зд. 2-ое / . . ктіонов , . . едведєв, . . вченко, . . ігун, . . ейко, . . кісько. - рьков : построф, 2012.-150 с.

3. ктіонов . . труктур т порядок використ ння б зи д них “л стивості грунтів кр їни” ( нструкція) / . . ктіонов , . . едведєв, . . вченко, . . ігун, . . ейко, . . кісько. - рків : построф, 2010. - 96 с.

4. сипчук. . риродно-сільськогоспод рське р йонув ння кр їни / . . сипчук. - . : рож й, 2008. - 191 с. 
5. т. 70406 кр їн,$\quad{ }^{51}$ G 01 N 33/24 (2006.01). посіб оцінки фізичної якості грунту / . . ктіонов , . . едведєв, . . ліско, . . ігун, . . ейко; вл сник ціон льний н уковий центр “нститут грунтозн вств т грохімії імені . . околовського”. - U 2011 13744; з явл. 22.11.2011; опубл. 11.06.2012, юл. № 11.

6. очвенн я к рт кр инской . сшт б 1:2 500000 . кр почвоведения и грохимии им. . . . околовского / [под. ред. . . рупского] // л вное упр вление геодезии и к ртогр фии при овете инистров ( ). - ., 1977.

7. епков . . риродно-сельскохозяйственное р йониров ние кр инской / . . епков, . . нш, . . оско, . . еревянко, . . озумный, . . еревицкий // грохимия и почвоведение. - 1985. - ып. 48. - . 8-22.

8. Doran J. W., Parkin T. B. Quantitative indicators of soil quality: a minimum data set / J. W. Doran, T. B. Parkin // Methods for assessing soil quality / [J. W. Doran \& A. J. Jones, eds] / SSSA, Spec.publ. N 49. - Madison, Wisconsin, USA, 1996.

9. Karlen I. D. A framework for evaluation physical and chemicsl indicators of soil quality / I. D. Karlen, D. E. Stott // In Defining soil quality for a sustainable environment. J. W. Doran, D. C. Coleman, D. F. Bezdicek, B. A. Stewart (eds.). Soil Sci. Soc. Am. Special publication. - N 35. - 1994. - P. 53-72.

\author{
m ття:н дійшл до ред кцї̈ 25.04.2013 \\ доопр изьов н 28.05 .2013 \\ прийнят до друку 17.06.2013
}

\title{
REGISTER OF STANDARD PARAMETERS OF SOIL PHYSICAL QUALITY FOR ARABLE LAND OF UKRAINE
}

\author{
Tetiana Laktionova, Oksana Bigun, Sergiy Sheyko, Svitlana Nakisko \\ The National Science Center \\ "Institute for Soil Science and Agricultural Chemistry named after.. . Sokolovsky", \\ Chaikovskiy St., 4, UA - 61024, Kharkiv, Ukraine, \\ e-mail: tnlaktionova@ukr.net
}

The algorithm has been developed and creation of the register for standard physical parameters of the mane arable soils has been started on the basis of a multipurpose database of relational type "Ukrainian soil properties". Soils are positioned in space of provinces of nature-agricultural zoning of Ukraine. The purpose of work is an estimation of soil physical quality. Calculations of the integrated index of soil physical quality are carried out according to the way developed by authors. The method is based on definition of soil physical quality on 7 basic physical properties. Nature-agricultural zoning is a spatial basis, and a province - the smallest spatial unit. Soil physical quality for different types has been compared in borders of each province by relative criteria.

Key words: soil physical quality index; standard; nature-agricultural zoning; province. 


\author{
тьян ктионов, кс н игун, ергей ейко, ветл н кисько \\ цион льный н учный центр “ нститут почвоведения и грохимии имени . . околовского”, \\ ул. йковск я, 4, 61024, г. рьков, кр ин, \\ e-mail: tnlaktionova@ukr.net
}

основе многофункцион льной $б$ зы д нных реляционного тип “ войств почв кр ины” p зр бот но лгоритм и н ч то созд ние реестр эт лонных физических п р метров основных п хотных почв кр ины, позициониров нных в простр нстве провинций природносельскохозяйственного р йониров ния, с целью оценки их физического к честв. счеты интегриров нного индекс физического к честв почвы выполнено в соответствии с $\mathrm{p}$ зр бот нным втор ми способом, который б зируется н определении грофизического потенци л почвы по 7 основным физическим свойств м. ростр нственной основой избр но природносельскохозяйственное р йониров ние, н именьшей простр нственной единицей - провинцию.

примере основных п хотных почв в евобережных провинциях зоны $е$ есостепи и зоны тепи пок 3 но порядок р счетов. о относительным индекс м выполнено ср внение физического к честв почв р зных типов в предел х к ждой провинции.

лючевые слов : индекс физического к честв почвы, эт лон, природносельскохозяйственное р йониров ние, провинция. 